\title{
PHENINDIONE NEPHROPATHY WITH RECOVERY: STUDIES OF MORPHOLOGY AND RENAL FUNCTION
}

\author{
H. A. LeE, B.Sc.(Lond.), M.B.(Lond.), M.R.C.P. \\ Medical Registrar \\ C. E. A. Holden, M.B., B.S.(Lond.) \\ Urological Registrar \\ King's College Hospital, London, S.E. 5
}

VARIOUS hypersensitivity reactions secondary to phenindione therapy have been described since its introduction in 1947. Amongst the most severe reactions are those involving the kidney. Transient albuminuria is not uncommon following phenindione therapy (Coon, Hodgson and Dennis, 1953; Goodman and Gilman, 1955). There have been seven reported cases of more severe renal involvement, in four of which the renal morphology has been known (Barritt and Jordan, I960; Postgraduate Medical School of London, I960; Galea, Young and Bell, 1963; Baker and Williams, 1963). Only in the last case was renal function investigated fully and correlated with the morphological changes. A further example of phenindione nephropathy, with a successful outcome of medical management, is reported to illustrate a type of renal lesion and change in renal function due to phenindione and to compare it with the case reported by Baker and Williams (1963).

\section{Case Report}

A fit civil servant, aged 55 , fell off a ladder on March 27,1963 , and sustained a fracture of the left tibia. On March 30 an open reduction of the fracture was performed, and the leg was immobilized in an above-knee plaster. Although the post-operative course was satisfactory it was decided on April 7 to treat the patient with phenindione to prevent phlebo-thrombosis.

On May I the patient, then at home, felt unwell, was pyrexial and developed a widespread erythematous skin rash. He was given antihistamines but with little effect. On May 4, because of continuing rash, fever and general malaise, the patient's general practitioner discontinued the phenindione therapy. The patient had been taking the drug for 28 days and had received a total dosage of $2.83 \mathrm{~g}$. On May 7 the patient was seen by a dermatologist who considered that the rash was probably due to phenindione sensitivity and prescribed cortisone and further antihistamines.

However, the patient continued to experience malaise, had shivering attacks and the rash become more extensive. He was admitted to a nursing home on May r3, when he had a temperature of $103^{\circ} \mathrm{F}$. $\left(39.5^{\circ} \mathrm{C}\right.$.). The rash was an extensive erythematous maculo-papular one, becoming scaly over the face, neck and arms. His urine output at that time was normal and his blood urea $37 \mathrm{mg}$./100 ml. Other investigations were:- ESR $23 \mathrm{~mm}$./hour; Hb. I5 g./100 ml.; PCV 46\%; MCHC
$34 \%$; wbc $12,200 /$ cu. mm.; neutrophils $80 \%$, lymp cytes $12 \%$, eosinophils $5 \%$, and monocytes $3 \%$. Some lymphocytes were noted to have unduly prominent cytoplasm. Total serum protein $6.1 \mathrm{~g} / 100 \mathrm{ml}$., normal albumin: globulin ratio. Liver function thts were normal. Serum glutamic-pyruvic transaminase 55 i.u. $/ \mathrm{ml}$.

$\omega$

By May I 5 the patient had developed a frank exfoliafifye dermatitis and was having frequent rigors. His urine output was $500 \mathrm{ml} . / 24$ hours in spite of adequate fitid intake.

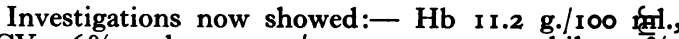
PCV $36 \%$, wbc $13,500 / \mathrm{cu}_{\text {. mm., neutrophils } 7 \mathrm{7} \%}$ lymphocytes $13 \%$, eosinophils $8 \%$, monocytes $4 \%$, plasma cells 4\%. Again unusual lymphocytesovith abundant basophilic cytoplasm and large reticglafed nuclei were seen. Turk cells were also seen. Sjerum glutamic-pyruvic transaminase was now 203 i.u./mi

On May 17 urine output fell to $390 \mathrm{ml} . / 24$ hours blood urea was $160 \mathrm{mg} . / 100 \mathrm{ml}$. Urine microscềy showed 3 leucocytes per high power field, no red blegd cells or organisms. There was moderate albuminug⿵ia. Urine urea was $660 \mathrm{mg} . / 100 \mathrm{ml}$.

On May 18 he was transferred to this Unit. Examintation showed an obese, anxious man with widesprêad exfoliative dermatitis. He was not jaundiced, nor was there any lymphadenopathy. Blood pressure was I $30 \% 0$ $\mathrm{mm}$. $\mathrm{Hg}$, the JVP was raised I cm., and the pulse $80 /$ min. and regular. There were bilateral basal medigm crepitations in the chest and a sacral pad of œdema. The liver edge was palpable one inch below the right costal margin. There was no splenomegaly.

Investigations. - $\mathrm{Hb} 9.8$ g./100 ml., PCV $38 \%$, wbc 13,600/cu. mm., neutrophils $59 \%$, lymphocytes $268 \%$, eosinophils $11 \%$, monocytes $4 \%$, with again mâny abnormal mononuclear cells; ESR $68 \mathrm{~mm}$./hougr; prothrombin time 19 seconds (control 16 seconds); serum glutamic-pyruvic transaminase 25 units/mitr.; serum glutamic-oxaloacetic transaminase 4I units/ng; blood urea $235 \mathrm{mg}$./ $100 \mathrm{ml}$; ; serum sodium I20m Eq serum potassium $5.1 \mathrm{mEq} . / 1$; serum chloride $90 \mathrm{mEq}$; ; serum bicarbonate $16 \mathrm{mEq} . / 1$; liver function tests normal; serum bilirubin $0.5 \mathrm{mg} . / 100 \mathrm{ml}$.

Urine examination showed moderate proteinuria weth numerous red and white cells. There were no casts. Urine urea concentration $920 \mathrm{mg} . / 100 \mathrm{ml}$. Uríne sodium $26 \mathrm{mEq}$./1, potassium $24 \mathrm{mEq}$./1, osmolaqty $156 \mathrm{mOsm} / \mathrm{kg}$. Plasma osmolarity $256 \mathrm{mOsm} / \mathrm{kg}$. Plain $\mathrm{X}$-rays of the abdomen showed the kidneys to be? normal shape, size and outline. Chest X-ray normgl. ECG normal.

\section{Progress}

Artificial hæmodialysis was performed using the Kब्ff 


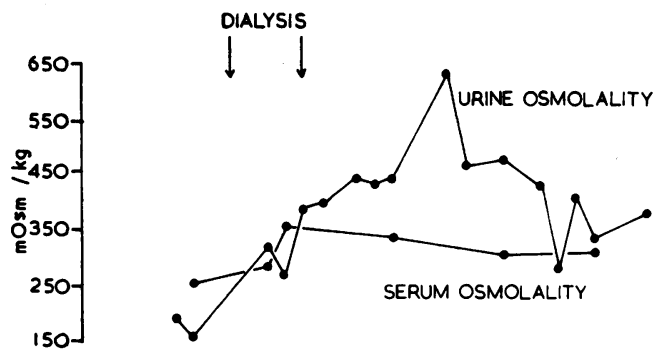

ำ
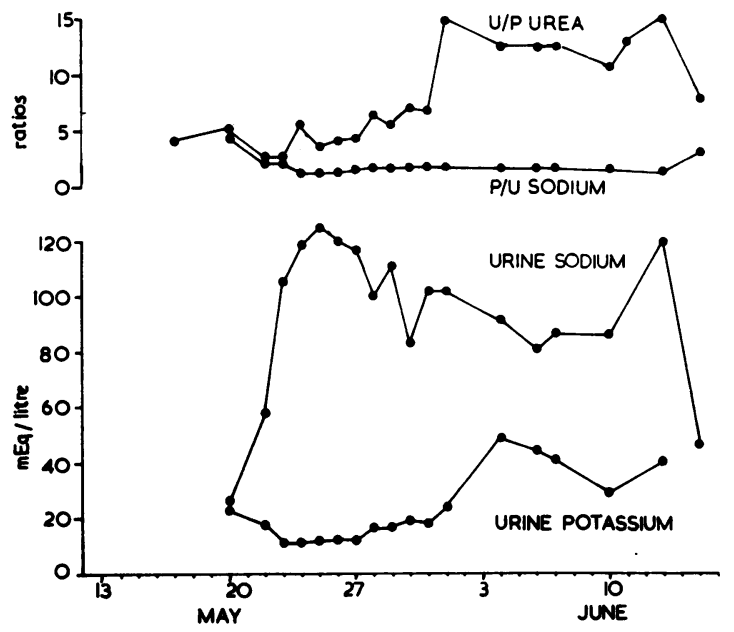

FIG. I.-Urine and serum osmolality values and urinary electrolytes during the onset and recovery of the oliguric renal failure.

twin coil apparatus, on May 20, because of rising blood urea, falling serum bicarbonate, virtual anuria $(22 \mathrm{ml} . / 24$ hours) and the known seriousness of this condition. Treatment with prednisone, $40 \mathrm{mg}$. daily, was begun on May 21 on the basis that the skin and the renal lesions were the result of a hypersensitivity reaction to phenindione and was continued in diminishing dosage unti June 8 when a good urine output had been achieved.

Following the first hæmodialysis the blood urea fell to $130 \mathrm{mg}$. $/ 100 \mathrm{ml}$., the bicarbonate rose to $25 \mathrm{mEq} . / 1$ and the serum potassium fell to $3.3 \mathrm{mEq}$./1 (See Fig. 2).

A second hæmodialysis was required on May 24 and thereafter the blood urea gradually fell and reached almost normal levels by June I 5. By June 7 the patient's skin had returned to normal. Although abnormal mononuclear cells had disappeared from the blood films by May 29, there was still an eosinophilia of $12 \%(990 / \mathrm{cu}$. $\mathrm{mm}$.), al normochromic anæmia $(9.7 \mathrm{~g} . / 100 \mathrm{ml}$.) and an ESR of $68 \mathrm{~mm}$./ hour on June 15 when he was discharged. These findings showed continued activity of the hypersensitivity reaction.

A renal biopsy was performed on June 14 to gauge the degree of renal recovery. This had not been done earlier as the urine biochemistry had been characteristic of acute renal tubular necrosis.

The patient was readmitted on two more occasions for follow-up studies. On July 8 he still complained of occasional irritating rashes developing over various parts of his body. He was otherwise well. Examination revealed a maculo-papular rash on the arms, back and buttocks. He was clinically anæmic. When finally admitted on August I $_{3}$ he was symptom free and there
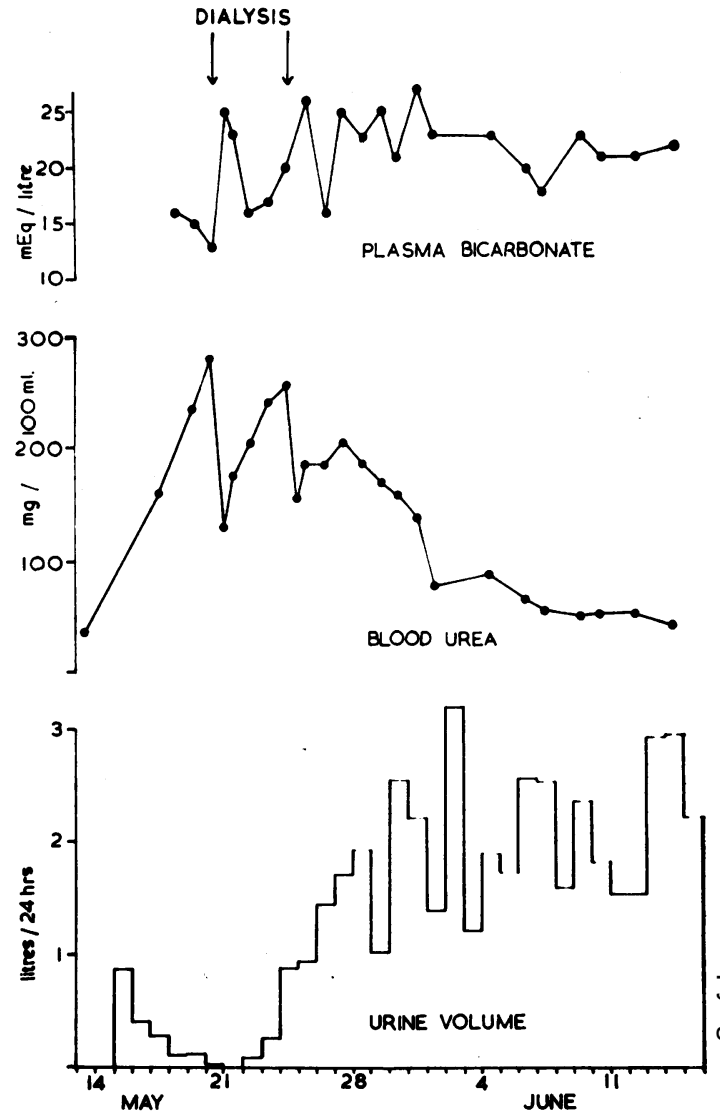

Fig. 2.-Blood urea, plasma bicarbonate and urine output during the onset and recovery of the oliguric renal failure.

were no abnormal physical findings. His blood pressure has remained at $140 / 90 \mathrm{~mm}$. $\mathrm{Hg}$.

The results of investigations during these two admissions are shown in Table 1 . The hæmatological findings, particularly the falling ESR and disappearance of the eosinophilia, are consistent with the slow subsidence of of a hypersensitivity reaction.

\section{Renal Function}

The changes in urine and serum findings throughout the recovery phase are shown in Figs. I and 2 . It is seen that the osmolality of the urine in the early stages was below that of the plasma, while the urine sodium concentration approached that of the serum and the urine potassium concentration was low. These findings together with the low urine/plasma (U/P) ratio of urea, are characteristic of acute tubular necrosis (Bull, Joekes and Lowe, 1950; Meroney and Rubini, 1959; Merrill, 1956; Sevitt, 1959). With recovery, the urine osmolality rose above that of plasma, the urine sodium concentration fell and the urine potassium concentration rose. The $U / P$ urea ratio rose slowly but there was $B$ much longer delay before there was any change in the plasma/urine $(\mathrm{P} / \mathrm{U})$ ratio of sodium. The slow approach of the urine electrolytes towards normality and likewise of the $U / P$ urea and $P / U$ sodium ratios long after the onset of the diuretic phase is typical of the recovery phase of acute tubular necrosis (Bull and others, 1950). 
TABLE I

Follow-up STUdies

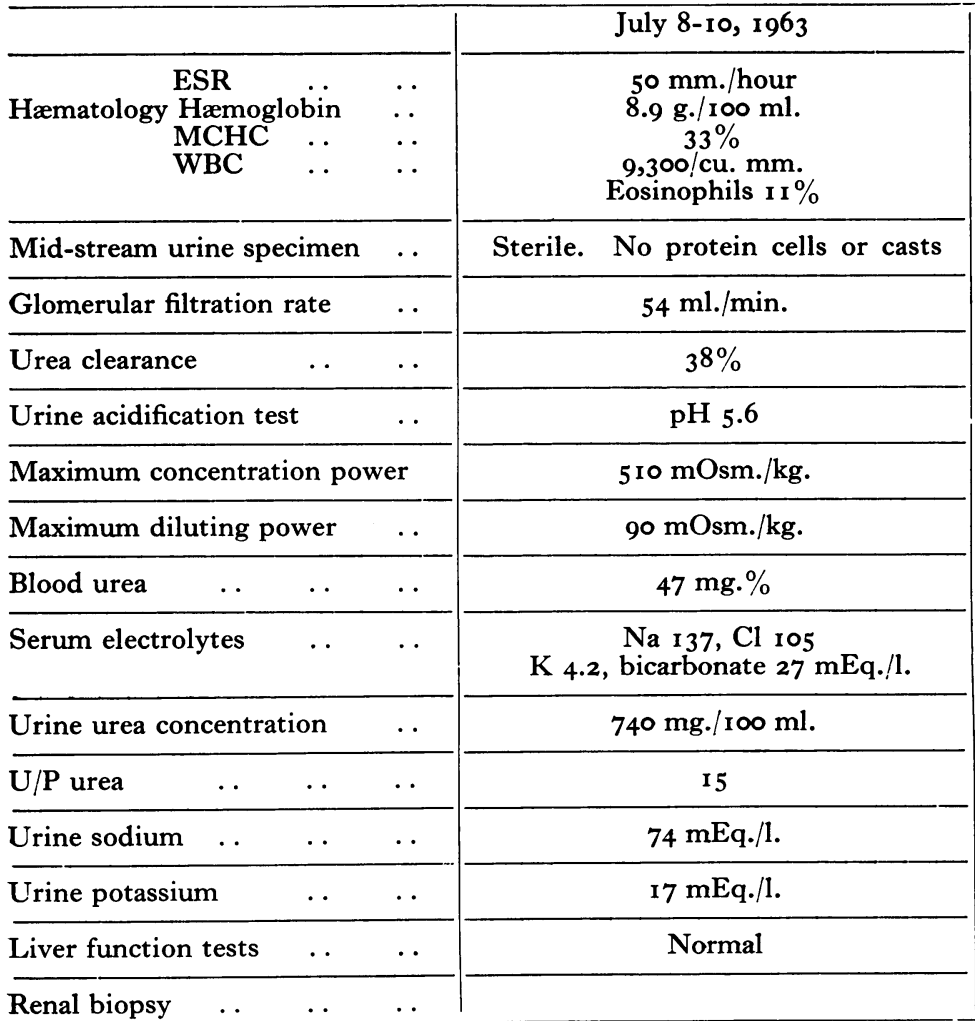

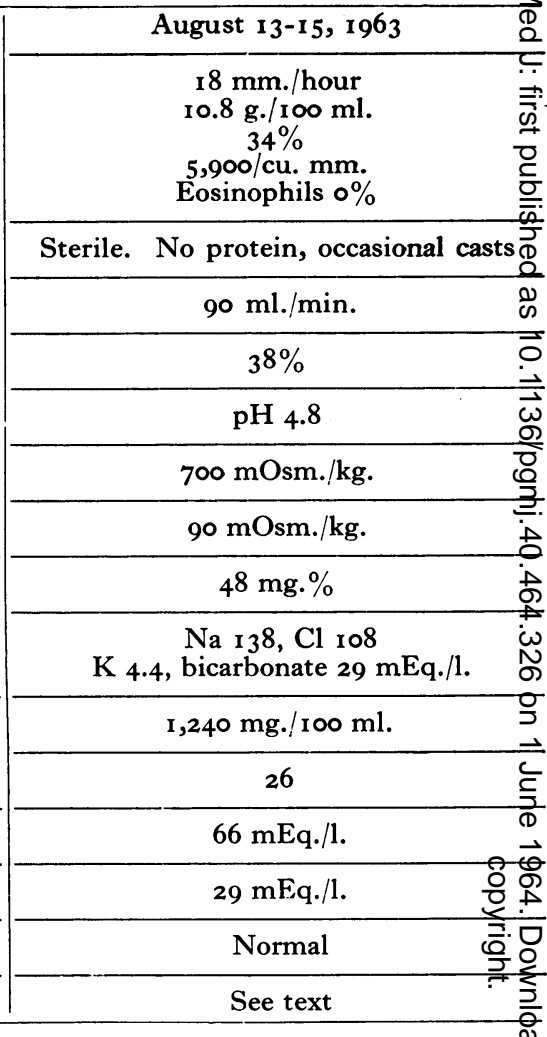

Mild to moderate albuminuria persisted until June 6, after which none was found. There was never any glycosuria. Throughout his stay in hospital there were a few red and white cells in his urine but no casts were seen, and no organisms were ever cultured. The urine acidity as measured in immediately voided urine (under paraffin oil) never fell below $\mathrm{pH}$ 6.I when measured between May 23 and 28. A urine acidification test (Wrong and Davies, 1959) performed on July 9 showed a fall in urine $\mathrm{pH}$ to 5.6 after the oral administration of ammonium chloride. This showed further improvement by August (Table I).

The glomerular filtration rate (GFR) using the inulin clearance method by continuous infusion was estimated on May 28. However, during the early phases of tubular dysfunction it is not possible to be sure that the inulin clearance represents glomerular filtration because some of the inulin may be passively reabsorbed across the walls of damaged tubules. Therefore, the early rising GFR values we obtained probably reflect tubular recovery. However, the later GFR values obtained when there was tubular recovery, are likely to be near correct indices of glomerular filtration (Bull and others, 1950). A urea clearance test carried out on June II gave a result of $29 \%$ (urine flow $15 \mathrm{ml}$. $/ \mathrm{min}$.).

The follow-up renal function studies (see Table I) all showed improvement though they had not reached normality and the evidence is that a very long interval elapses before they do (Lowe, 1952). The greatest deficit is still seen in renal tubular function tests (e.g. maximum concentrating power, urine electrolyte values) and this is in agreement with the findings of the second renfir biopsy.

Renal Biopsy was performed on June 14 by the peq cutaneous method using a Menghini needle. The biopsy report showed that the specimen contained seven glomeruli. There was a small cortical scar present which included a single hyalinized glomerulus. The remaining glomeruli were normal. There was some thickening of the glomerular capsules. No crescenfs were seen. The epithelium of both the distal and proximal tubules was swollen and granular or, in songe instances, necrotic. A few mitotic figures were seen suggesting that some of the epithelium was regenerating (Fig. 3). The tubular basement membranes wefe difficult to define in some areas, but most of them wese intact. The most striking feature was a cellular infilt tion, with a predominance of plasma cells, of the interstitial tissue, where there was some early fibrosis. A few eosinophils were seen.

The second renal biopsy, performed on August showed the following. The cellular infiltrate in the interstitial tissue persisted but it now consisted predominantly of lymphocytes. No eosinophils were seen and the plasma cells were fewer than in the previoms biopsy. Changes in the tubules were less marked then before but dilated tubules containing hyaline casts were still seen and there was a deposit of calcium in relation to a tubule. The glomerular basement membranes we probably thicker than before and less well definథd (Fig. 4). 


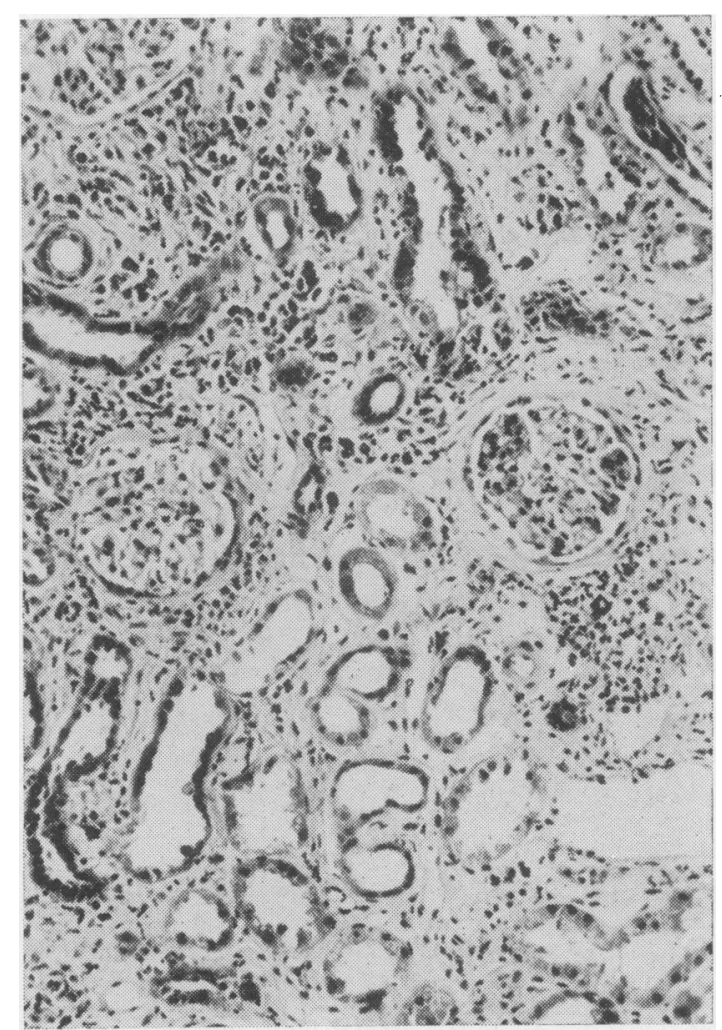

FIG. 3.-First biopsy, showing intense cellular infiltration of interstitial tissue and tubular necrosis. $(5 \mu$ section. Hæmatoxylin and eosin x 140).

\section{Discussion}

There can be little doubt that this patient's illness was due to phenindione hypersensitivity. He showed features typical of such a reaction:fever, exfoliative dermatitis, raised serum transaminase levels, eosinophilia and atypical mononuclear cells (Perkins, 1962). The patient had not received any other medication likely to have produced such a picture. The fact that the renal complications did not occur until some five weeks after commencement of phenindione seems consistent with the delay noted in previously reported cases (Kirkby, 1954; Barritt and Jordan, 1960; Galea and others, 1963; Postgraduate Medical School of London, 1960). The albuminuria, which was never severe in this patient, only persisted for $2 \mathrm{I}$ days although there was still considerable impairment of renal function $\mathbf{5 3}$ days later.

There have now been eight cases reported of severe renal complications following phenindione sensitivity (see Table 2). In five of these details of renal histology are available. The features of severe, acute tubular necrosis and reactive inflammation were seen in the case reported by Barritt and Jordan (1960). In the case from the Postgrad-

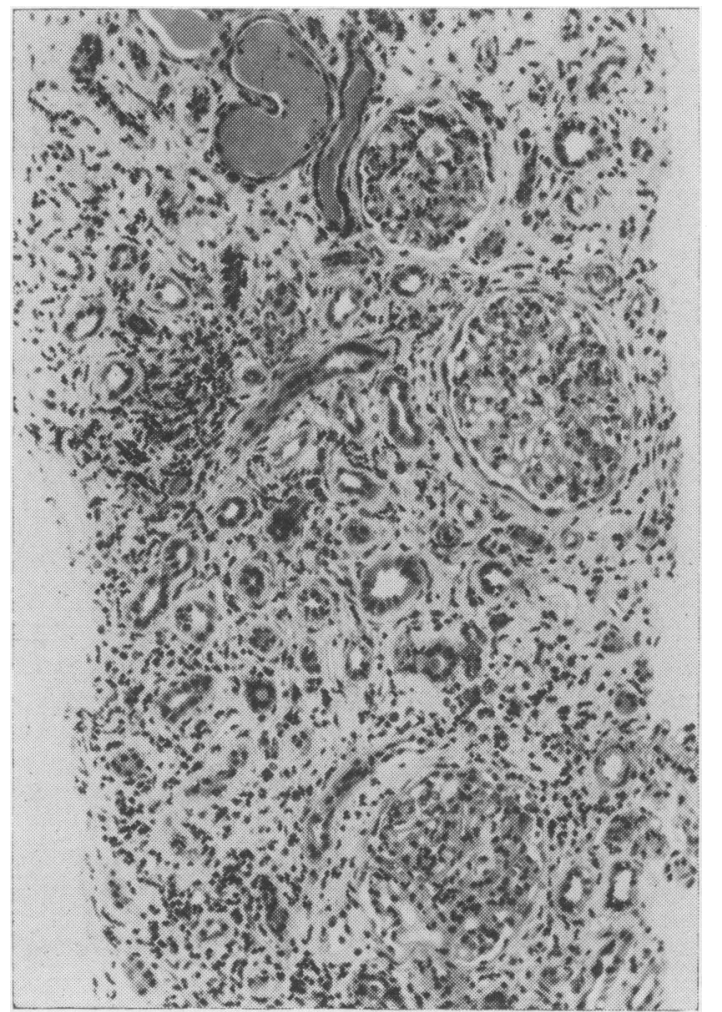

Fig. 4.-Second biopsy, showing considerable reduction in cellular infiltrate. There is less tubular damage and hyaline casts are seen in some tubules. Deposit of calcium in relation to one tubule. $(5 \mu$ section. Hæmatoxylin and eosin $x$ 140).

uate Medical School of London (1960), the histology was that of tubular necrosis with a more diffuse cellular infiltration by plasma cells and lymphocytes. The post mortem histology in the case reported by Galea and others (1963) showed tubular necrosis, interstitial œdema with plasma cell and lymphocyte infiltration and glomerular changes. The latter consisted of thickening of the basement membrane, swelling of the endothelial cells and the presence of neutrophils, plasma cells and occasional eosinophils in the glomerular tufts. The histology in the case reported by Baker and Williams (1963) was again that of patchy tubular necrosis and considerable inflammatory cell infiltration, mainly plasma cells and eosinophils with some foci of neutrophils. These authors stressed that their case was one of interstitial nephritis rather than tubular necrosis and presented biochemical data to support this contention.

This present case is in many respects similar to that of Baker and Williams (1963). The striking finding in the renal biopsy was that in addition to tubular necrosis there was a gross interstitial infiltration of plasma cells and eosinophils 
TABLE 2

Abstracts of Previous Case Reports

\begin{tabular}{|c|c|c|c|c|c|}
\hline Reference & $\begin{array}{l}\text { Primary condi- } \\
\text { tion requiring } \\
\text { anti-coagulants }\end{array}$ & $\begin{array}{l}\text { Duration and } \\
\text { dosage of } \\
\text { Phenindione }\end{array}$ & $\begin{array}{l}\text { Associated } \\
\text { reactions }\end{array}$ & $\begin{array}{l}\text { Evidence of renal } \\
\text { involvement }\end{array}$ & 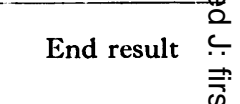 \\
\hline Kirkby, 1954 & $\begin{array}{c}\text { Myocardial } \\
\text { infarction }\end{array}$ & 5 weeks $3 g+$ & $\begin{array}{l}\text { Fever, rash, } \\
\text { jaundice, } \\
\text { agranulo- } \\
\text { cytosis }\end{array}$ & $\begin{array}{l}\text { Acute renal failure. } \\
\text { No histology }\end{array}$ & 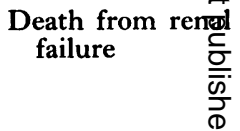 \\
\hline $\begin{array}{l}\text { Barritt and Jordan, } \\
1960\end{array}$ & $\begin{array}{l}\text { Pulmonary } \\
\text { embolism }\end{array}$ & 30 days & $\begin{array}{l}\text { Rash, fever, } \\
\text { diarrhœa }\end{array}$ & $\begin{array}{l}\text { Oliguric renal failure. } \\
\text { Necropsy showed } \\
\text { acute renal necrosis }\end{array}$ & $\begin{array}{l}\text { Death from rena } \\
\text { failure }\end{array}$ \\
\hline Tait, 1960 & $\begin{array}{c}\text { Myocardial } \\
\text { infarction }\end{array}$ & $\begin{array}{l}3 \text { months } \\
\log +\end{array}$ & Diarrhœa & $\begin{array}{l}\text { Nephrotic syndrome. } \\
\text { No histology }\end{array}$ & $\begin{array}{l}\text { Persistent } \\
\quad \text { albuminuria }\end{array} \overrightarrow{\vec{\omega}}$ \\
\hline $\begin{array}{l}\text { Brooks and } \\
\text { Calleja, } 1960\end{array}$ & $\begin{array}{c}\text { Myocardial } \\
\text { infarction }\end{array}$ & 26 days $2.4 \mathrm{~g}$ & $\begin{array}{c}\text { Fever, } \begin{array}{c}\text { rash } \\
\text { and jaundice }\end{array}\end{array}$ & $\begin{array}{l}\text { Proteinuria, R.B.C., } \\
\text { W.B.C., casts. } \\
\text { No histology }\end{array}$ & Recovery \\
\hline $\begin{array}{l}\text { Postgraduate } \\
\text { Medical School, } \\
\text { London, 1960 }\end{array}$ & $\begin{array}{l}\text { Pulmonary } \\
\text { hypertension }\end{array}$ & 2 months & & $\begin{array}{l}\text { Oliguric renal failure. } \\
\text { Both biopsy and } \\
\text { necropsy showed } \\
\text { acute tubular ne- } \\
\text { crosis and inter- } \\
\text { stitial plasma cell } \\
\text { infiltration }\end{array}$ & 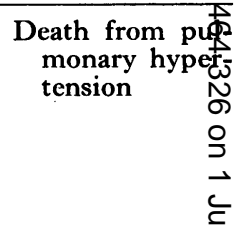 \\
\hline Galea et al., 1963 & Angina pcctoris & $3 \mathrm{I}$ days $3.8 \mathrm{~g}$ & Rash, jaundice & $\begin{array}{l}\text { Acute oliguric renal } \\
\text { failure. Thickening } \\
\text { of glomerular base- } \\
\text { ment membrane }\end{array}$ & $\begin{array}{c}\begin{array}{c}\text { Death from ren } \\
\text { failure }\end{array} \\
\end{array}$ \\
\hline $\begin{array}{l}\text { Baker and Williams, } \\
\quad 1963\end{array}$ & Angina pectoris & I9 days & $\begin{array}{l}\text { Fever, rash, } \\
\text { jaundice, } \\
\text { atypical } \\
\text { lymphocytes }\end{array}$ & $\begin{array}{l}\text { Acute renal failure. } \\
\text { Biopsy showed } \\
\text { interstitial nephri- } \\
\text { tis and tubular } \\
\text { necrosis }\end{array}$ & 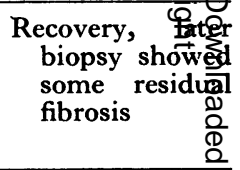 \\
\hline Present case & Fractured tibia & 28 days $2.8 \mathrm{~g}$ & $\begin{array}{l}\text { Fever, exfolia- } \\
\text { tive derma- } \\
\text { titis }\end{array}$ & $\begin{array}{l}\text { Acute renal failure. } \\
\text { Tubular necrosis. } \\
\text { Plasma cell infiltra- } \\
\text { tion }\end{array}$ & $\begin{array}{r}\text { Recovery. Songe } \\
\text { permanent to } \\
\text { bular damage } \\
\text { 导 }\end{array}$ \\
\hline
\end{tabular}

The biochemical data were characteristic of renal tubular necrosis.

We suggest that in these cases the renal tubular cells predominantly have become sensitized to phenindione and subsequently necrose and that the interstitial infiltration represents the histological picture of a sensitivity reaction. Thus, depending upon the severity and the particular site of this reaction in the kidneys, i.e. whether in tubules, interstitial tissue or glomeruli, one will find varying histological pictures. There may be a mild interstitial nephritis (Burns and Desmond, 1958), a severe interstitial nephritis with some tubular necrosis (Baker and Williams, 1963), or a severe interstitial nephritis, acute tubular necrosis and glomerular involvement as in this case and that recorded by Galea and others ( 1963$)$. In the case of Baker and Williams the urine investigations were not wholly characteristic of tubular necrosis, agreeing with their renal biopsy, but a minority of tubules may have been involved. It is, therefore seen that interstitial nephritis and tubular necrosis are part of the same pattern of hypersensitivity reactions in the kidney (Kimmelstiel, 1938; Melnick, 1943).

The reason for the oliguria is speculative. Probably multiple factors operate such as acute interstitial œdema compressing tubules (Peters, 1945) already narrowed by their contained debris (Maluf, I949; Harrison, Bunting, Ordway and Albrink, 1947) or tubular necrosis allowing back diffusion of water and perhaps reduced glomerular filtration subsequent upon glomerular membrafe or capillary changes. Compression of the tubules by interstitial œdema may also cause considerabte local anoxia.

It would appear logical to use steroid therapy such patients since the renal and skin lesions age 
due to marked cellular infiltration secondary to a hypersensitivity reaction. In this case the urine output began to increase the day following commencement of prednisone therapy but this may have been coincidence. Baker and Williams also thought it was coincidental that their patient passed urine four hours after his first dose of prednisolone. In the present case it might have been better to continue steroid therapy longer in view of the persistently raised ESR and continuing eosinophilia and the abnormal renal function studies.

The second renal biopsy shows that there will be some permanent renal damage but nevertheless the degree of recovery has been remarkable. It is interesting to note how closely the renal biopsy findings have mimicked those of chronic pyelonephritis. Baker and Williams (1963) have put forward the possibility that some cases of chronic pyelonephritis may take origin in a kidney which has been the site of a hypersensitivity reaction to some unidentified allergen. As they rightly point out, the only solution will be found in the longterm follow-up of cases where hypersensitivity was clearly established.

Phenindione nephropathies seem to occur after prolonged use of the drug and even after it has been stopped. The drug must, therefore, be stopped and steroid therapy begun at the earliest indication that a sensitivity reaction is developing. Since the renal complications are so severe, it would seem expedient to teach patients on phenindione therapy to test their urine daily for albumin with the simple 'Albustix' method. They should be instructed to report back to hospital should the test become positive as this is probably the earliest sign of renal involvement. Healing of the renal tissue is slow and steroid therapy may need to be prolonged.

\section{Summary}

A 55-year-old male was given post-operative prophylactic phenindione therapy after an open reduction of a fractured left tibia. He developed fever, rigors and skin rashes 28 days after starting the drug. Eleven days later he developed oliguric renal failure and required artificial hæmodialysis on two occasions. Follow-up renal function studies have shown a fairly good recovery although some permanent renal damage has occurred. Correlation between morphological and biochemical changes has been discussed. The management of such cases is briefly considered.

We are grateful to Dr. J. Anderson for his advice in preparing this paper. Our thanks are also due to Dr. L. J. Beilin who performed the renal biopsies and to Dr. G. Stirling who reported on them.

\section{REFERENCES}

Baker, S. B. DE C., and Williams, R. T. (1963): Acute Interstitial Nephritis due to Drug Sensitivity, Brit. med. ., i, 1655 .

Barritt, D. W., and Jordan, S. C. (1960): Anticoagulant Drugs in the Treatment of Pulmonary Embolism, Lancet, i, 1309.

Bull, G. M., Joekes, A. M., and Lowe, K. G. (1950): Renal Function Studies in Acute Tubular Necrosis, Clin. Sci., 9, 379 .

Burns, C., and Desmond, F. B. (1958): Sensitivity to Dindevan (Phenylindanedione): Report of a Case with Review of Literature, N.Z. med. F., 57, 283.

Coon, W. W., Hodgson, P. E., and Dennis, E. W. (r953): Therapeutic Evaluation of a New Anticoagulant Phenylindandione, Ann. Surg., 138, 467.

Galea, E. G., Young, L. N., and Bell, J. R. (1963): Fatal Nephropathy due to Phenindione Sensitivity, Lancet, i, 920.

Goodman, I.. S., and GilmaN, A. (1955): 'Pharmacological Bases of Therapeutics', p. 1518. New York: Macmillan.

Harrison, H. E., Bunting, H., Ordway, N. K., and Albrink, W. S. (1947): Pathogenesis of Renal Injury Produced in Dog by Hemoglobin or Methemoglobin, $\mathcal{F}$. exp. Med., 86, 339.

Kimmelstiel, P. (1938): Acute Hematogenous Interstitial Nephritis, Amer. F. Path., $14,737$.

KIRKBY, K. (1954): Agranulocytosis following Treatment with Phenylindandione, Lancet, ii, 580.

Lowe, K. G. (1952): The Late Prognosis in Acute Tubular Necrosis, Lancet, i, 1,086.

Maluf, N. S. R. (1949): Factors Inducing Renal Shutdown from Lysed Erythrocytes. An Experimental Study, Ann. Surg., I30, 49.

Melnick, P. J. (1943): Acute Interstitial Nephritis with Uræmia, Arch. Path., 36, 499.

Meroney, W. H., and Rubini, M. E. (1959): Kidney Function During Acute Tubular Necrosis; Clinical Studies and a Theory, Metabolism, 8, I.

Merrill, J. P. (1956): Electrolyte Changes in Renal Failure, Metabolism, 5, 419.

Perkins, J. (1962): Phenindione Sensitivity, Lancet, i, 127.

Peters, J. T. (1945): Oliguria and Anuria due to Increased Intrarenal Pressure, Ann. intern. Med., 23, 221.

Postgraduate Medical School of London (1960): A Case of Pulmonary Hypertension, Brit. med. F., ii, i2i 9.

SevitT, S. (1959): Pathogenesis of Traumatic Uræmia, Lancet, ii, 135.

Wrong, O., and Davies, H. E. F. (1959): The Excretion of Acid in Renal Disease, Quart. J. Med., $28,259$. 